\title{
People's Houses as Answers to the Challenges of Modernity in Europe and Russia
}

\author{
Elena V. Alekseeva, Elena Y. Kazakova-Apkarimova \\ Institute of History and Archeology of the Ural Branch of the Russian Academy of Sciences; \\ 16, S. Kovalevskaya St., Yekaterinburg, 620108, Russia; \\ alekseeva167@mail.ru, apkarimova@mail.ru
}

\begin{abstract}
The article is devoted to a pioneer comparative study of the appearance and evolution of people's houses in Western Europe and Russia in the second half of the XIX - early XX century. The institutional approach chosen by the authors is complemented by a historical and comparative method of studying the phenomenon of people's houses. The goals of their creation and features of the activity, due to the political, economic and sociocultural historical realities of individual countries, are analyzed. Research revealed that people's houses in Europe and in Russia were created at the same historical period - the modern era. A historiographical comparative study using new historical sources showed that in Western European countries and in the Russian Empire, the state did not play a major role in this matter, although some of the people's houses were opened by monarchs, and state policy (opposing promotion of cultural leisure to the alcoholization of the population) could contribute to the development of civil society initiatives. The performed study proves that for both European countries and Russia, private and public initiatives in establishing people's houses (primarily the cooperative movement) played a decisive role. In Russia, it is important to point out the sociocultural policy of the zemstvos, their financial support when building people's houses. The article shows the obvious differences in the history of people's houses in Western European countries and in Russia, due to the late formation of the party system in Imperial Russia. In Europe, one can meet many examples of the creation of people's houses by political parties and generally note the high level of politicization of these institutions. In Russian reality non-political nature of people's houses is obvious, they were mostly cultural and educational public institutions that were further subjected to the process of politicization (under revolutionary conditions). In conclusion, the authors acknowledge big historical significance of people's houses as civil society institutions in Russia and abroad, taking into account such principles of their functioning as independence, voluntariness, social activism and civic consciousness.
\end{abstract}

Keywords: people's house, culture, enlightenment, civil society, cooperation, labor and trade union movement, Western Europe, Russian Empire, heritage

For citation: Alekseeva, Elena V., and Kazakova-Apkarimova, Elena Y. "People's Houses as Answers to the Challenges of Modernity in Europe and Russia." RUDN Journal of Russian History 19, no. 4 (November 2020): 952-964. https://doi.org/10.22363/2312-8674-2020-19-4-952-964

\section{Народные дома - европейский и российский «ответы» на культурно-мировоззренческие «вызовы» эпохи модерна}

\author{
Е.В. Алексеева, Е.Ю. Казакова-Апкаримова \\ Институт истории и археологии Уральского отделения Российской академии наук; \\ 620108, Россия, Екатеринбург, ул. С. Ковалевской, 16; \\ alekseeva167@mail.ru, apkarimova@mail.ru
}

Аннотация: Статья впервые посвящена компаративному исследованию появления и эволюции народных домов в Западной Европе и России во второй половине XIX - начале XX в. Выбранный авторами институциональный подход дополняется историко-сравнительным методом

(C) Alekseeva E.V., Kazakova-Apkarimova E.Y., 2020

(c) (i) This work is licensed under a Creative Commons Attribution 4.0 International License https://creativecommons.org/licenses/by/4.0/ 
исследования феномена народных домов. Показаны цели их создания и особенности деятельности, обусловленные политическими, экономическими, социокультурными историческими реалиями отдельных стран. Установлено, что народные дома в Европе и в России возникли в одно историческое время - эпоху модерна. Историографическое сравнительно-историческое исследование с привлечением новых исторических источников показало, что в западноевропейских странах и в Российской империи государство не играло главной роли в данном вопросе, хотя отдельные народные дома открывались монархами, а государственная политика (противопоставляющая алкоголизации населения пропаганду культурного досуга) могла способствовать развитию инициативы гражданского общества. Выявлено, что и в странах Западной Европы, и в России определяющую роль в создании народных домов играли частные инициативы и общественные движения (прежде всего кооперативное). В России важно отметить социокультурную политику земств, их финансовую поддержку при открытии народных домов. В статье показаны очевидные различия в истории народных домов в западноевропейских странах и в России, обусловленные поздним становлением партийной системы в позднеимперской России. Если в Европе можно встретить немало примеров создания народных домов политическими партиями и в целом отметить высокий уровень их политизации, то для российской действительности была типичнее неполитическая природа народных домов как культурно-просветительских общественных институтов, в дальнейшем подверженных процессу политизации (в революционных условиях). В заключении делается вывод о большом историческом значении народных домов как институтов гражданского общества в России и за рубежом, учитывая такие принципы их функционирования, как самостоятельность, добровольность, общественный активизм и гражданственность.

Ключевые слова: народный дом, культура, просвещение, гражданское общество, кооперация, рабочее и профсоюзное движение, Западная Европа, Российская империя, наследие

Для цитирования: Алексеева Е.В., Казакова-Апкаримова Е.Ю. Народные дома - европейский и российский «ответы» на культурно-мировоззренческие «вызовы» эпохи модерна // Вестник Российского университета дружбы народов. Серия: История России. 2020. Т. 19. № 4. C. 952-964. https://doi.org/10.22363/2312-8674-2020-19-4-952-964

\section{Introduction}

With the development of modern society and the attendant rise of a more rational worldview, the public became increasingly interested in the sphere between the sacred and universal on the one hand and familiar everyday life on the other. Rising levels of education and culture among the working masses led to the emergence of institutions and organizations to meet their needs, including schools, social circles, courses, public libraries, reading rooms, and theaters. One entirely new answer to the cultural and intellectual challenges of the time was the emergence of people's houses. As they evolved during the second half of the $19^{\text {th }}$ and early $20^{\text {th }}$ centuries they emerged as important public institutions that reflected the desire for self-identification and the search for new forms of cultural and political socialization among many workers. These institutions made a significant contribution to the formation of the population's civic culture, providing insights into the evolution of civil society in both Europe and Russia.

People's houses emerged in the context of the rise of the labor movement, and their premises became a platform for various public organizations. The buildings that housed them were often financed by workers' cooperatives and involved voluntary labor. As a rule, they were built in the residential areas of workers, standing out by their size and architecture. People's houses had a significant impact on the cultural landscape as the center of social and cultural life, not only in many large cities, but also in small towns as well as rural settlements.

People's houses were strongly influenced by national history and regional specifics. Thus, their emergence as an initiative from below, i.e. through the cooperative efforts of workers, bear the imprint of the utopian ideas of Roger Owen, Henri, Count de SaintSimon and Charles Fourier. One of the oldest people's houses in France, the Maison $\mathrm{du}$ peuple in Saint-Claude, is an intriguing example and is also interesting from the perspective of cultural heritage. In France, active work is still being done on the matter.

In recognition of the historical significance of the People's House in Saint-Claude, since 1984 the association "La Fraternelle" has been working to "perpetuate the memory of the activities of its predecessors", by ensuring its continuity, especially in the field of 
public education and art, by organizing classes and excursions for students of all levels, temporary exhibitions, conferences and round tables. ${ }^{1}$ The Association also keeps important archives of cooperative unions, public associations, political, cultural and sports groups, and stores them in national and international centers for documentation of social history (CODHOS, IALHI, AMSAB), which allow researchers to work with them. ${ }^{2}$ Thus, SaintClaude features the historical building of the old People's House, and the democratic spirit of culture, enlightenment and creativity continues to develop within its walls.

Some steps to preserve the cultural heritage of the institutions in question are also being taken in Russia. The People's House of Nicholas II in St. Petersburg has long had a music hall. The Cheliabinsk People's House is now home to the Drama Youth Theater. The Bashkir Opera and Ballet Theater (in which Rudolph Nureyev danced) in Ufa has been located in the Aksakovskii People's House since 1938. The Vvedenskii People's House in Moscow, where the famous theater expert Aleksei Bakhrushin worked from 1907, and "Carnival Night" was filmed in 1956, was rebuilt as the Palace on the Yauza in 2008. In 2000-7, the people's house in Barnaul was restored with federal and regional money. As home to the Philharmonic Society, it hosts concerts, poetry evenings and exhibitions, thereby providing some historical continuity. ${ }^{3}$ However, the condition of more modest, non-stone people's houses in the provinces remains deplorable; the fate of the wooden People's House in Pervouralsk is a sad example. ${ }^{4}$

Foreign scholars often study people's houses in the context of the development of political consciousness, including communism, among residents of specific settlements. Max Hastings has written a book about the matter, Halluin la rouge 1919-39, aspects d'un communisme identitaire (Halluin the red: Aspects of a Communist Identity) ${ }^{5}$ while the article by P. Cossart and J. Talpin consider the People's House in Roubaix, a town near Lille in northern France, as a community center that became an important place for the politicization of the working class. ${ }^{6}$

The historical and cultural aspects of people's houses are the subject of a number of monographs. Perhaps the most significant is the Belgian book Maisons du Peuple, Architectures pour le peuple, Belgique, Allemagne, Autriche, France, Grande Bretagne, Italie, Pays Bas, Suisse (People's houses. Architecture for the people. Belgium, Germany, Austria, France, Great Britain, Italy, Netherlands, Switzerland). ${ }^{7}$ However, despite the work's wide geographical scope, it focuses on people's houses in Belgium. Meanwhile, F. de Luis Martin and L.A. Gonzalez's Las Casas del Pueblo socialistas en España (1900-36) (Socialist People's houses in Spain (1900-36)), published in 1997, studies the phenomenon in Spain. ${ }^{8}$ The specialist of interwar urban architecture A. Katz, looks at people's houses on the periphery of Paris in 1914-40, and examines how they evolved, their architecture both in its symbolic functions and in the context of modernization. ${ }^{9}$ In the British Isles, people's houses were dif-

${ }^{1}$ Aurélie Edet. 2 Mar 2017. A Saint-Claude, la mémoire toujours vivante de la Maison du people, https://autogestion.asso.fr/a-saint-claude-la-memoire-toujours-vivante-de-la-maison-du-peuple/.

${ }^{2}$ La Frat, accessed January 5, 2020, www.maisondupeuple.fr.

${ }^{3}$ O.Yu. Konysheva, "The People's House in Barnaul is an architectural and cultural monument of the early XX century," Balandin readings, no. 1 (2015), accessed January 7, 2020, https:/cyberleninka.ru/ article/n/narodnyy-dom-v-g-barnaule-pamyatnik-arhitektury-i-kultury-nachala-xx-v.

4 S. Chernogubov, Narodnyy dom v Pervoural'ske, accessed Fabruary 6, 2020, https://uraloved.ru/ goroda-i-sela/sverdlovskaya-obl/narodniy-dom-pervouralsk

${ }^{5}$ Hastings, M. Halluin la rouge 1919-1939, aspects d'un communism identitaire (Paris: Presses University, 1991).

${ }^{6}$ P. Cossart, J. Talpin, "Les Maisons du Peuple comme espaces de politisation. Étude de la cooperative ouvrière la paix à Roubaix (1885-1914)," Revue française de science politique 62, no. 4 (2012): 583-610.

${ }^{7}$ Maisons du Peuple, Architectures pour le people. Belgique, Allemagne, Autriche, France, Grande Bretagne, Italie, Pays Bas, Suisse (Bruxelles: Archives d'Architecture Moderne, 1984).

${ }^{8}$ Las Casas del Pueblo socialistas en España (1900-1936). (Madrid: Ariel Historia, 1997).

${ }^{9}$ A. Katz, "Maisons du Peuple: Marking new Municipal Centers on the Parisian Periphery, 1914-1940," in Architecture de la Culture. Relais du pouvoir Européen. Proceedings of the DocoMomo International Conference, Paris, April 24, 2006 (Paris: DocoMomo International, 2009), 26-33. 
ferent in various parts of the kingdom. In Wales, they are known as "workmen's halls" or "workmen's institutes 10 ," while England and Scotland also had "miners' institutes."

Anke Hoffsten's study of the history and architecture of people's houses in Germany, Das Volkshaus der Arbeiterbewegung in Deutschland: Gemeinschafts bauten zwischen Alltag und Utopie (People's houses and the labor movement in Germany: public buildings between everyday life and utopia) ${ }^{11}$ considers their key role in providing workers with their own places of cultural leisure. The study covers some 300 of them, both significant architectural buildings and simple, temporary constructions, examining the connection between traditional styles and innovation in the context of the architectural discourse of modernity. As a result, Hoffsten concludes that people's houses strongly influenced modern urban architecture. She pays special attention to their use by the National Socialists. Her book also looks at the eventual fate of the people's houses.

The history of people's houses in Russia is studied in the context of various cultural, educational and charitable organizations of the late imperial era, which built them as, for example, guardianships of national sobriety, after the approval of the relevant Charter on December 20, 1894. According to the document, the tasks of local committees of guardianships of national sobriety included organizing anti-alcohol propaganda and cultural activities, such as people's houses; from 1897 to 1903 the guardianships built 137 people's houses. ${ }^{12}$ Working with sources in the Urals, ${ }^{13}$ M.R. Iusupov studied people's houses in the broad context of the zemstvos' educational activities. ${ }^{14}$ Meanwhile, N. V. Kazakova analyzed their history in pre-revolutionary Udmurtia, which at that time was part of Vyatka Province. ${ }^{15}$

Historians of Siberia have looked at the cooperative movement in Asian Russia, which pursued not only economic goals, but also helped raise the population's cultural level, in particular by setting up people's houses. In this regard, between 1916 and 1918 in Siberia 23 cooperatives opened seven libraries, two provincial reading rooms, ${ }^{16}$ book stores, seven people's houses, 10 cooperative courses, two cooperative schools, three theaters, and one cinema. ${ }^{17}$

${ }^{10}$ G.D. Nash, T.A. Davies, B. Thomas, Workmen's Halls and Institutes: Oakdale Workmen's Institute. National museum of Wales. Cathays Park (Cardiff: Cardiff University, 1995).

11 A. Hoffsten, Das Volkshaus der Arbeiterbewegung in Deutschland: Gemeinschafts bauten zwischen Alltag und Utopie (Köln; Wien; Weimar: Böhlau Verlag, 2017).

12 L.P. Rasskazov, A.V. Kuzmina, "Historiography of the Guardianship of Popular Sobriety in the Russian Empire," Law and State: Theory and Practice, no. 11 (2015), accessed February 4, 2020, https://kubsau.ru/ upload/iblock/d4f/d4f45b192b38838f97229ab87528aaf9.pdf

${ }^{13}$ D.Ye. Pel'kov, "Piteynaya reforma v Rossii i deyatel'nost' popechitel'stv o narodnoy trezvosti v 1895-1914 gg. (po materialam Ufimskoy gubernii)." In Yezhegodnaya bogoslovskaya konferentsiya parvoslavnogo Svyato-Tikhonovskogo gumanitarnogo universiteta (Moscow: [B.i.], 2012), 127-129; D.Ye. Pel'kov, "The first folk houses in the Ufa province (1895-1897)," Bulletin of the Chelyabinsk State Academy of Culture and Art, no. 3 (2012): 160-163; E.B. Druzhinina, "The first, not accidental, remarkable ... (to the $110^{\text {th }}$ anniversary of the building of the people's house in Chelyabinsk),"Museum Bulletin, no. 16 (2014): 64-68.

${ }^{14}$ M.R. Yusupov, "Educational activity of the zemstvos of the Urals at the turn of the XIX-XX centuries: people's houses," Bulletin of the Ryazan State University. S.A. Yesenin, no. 4 (2015), accessed January 10, 2020, https://cyberleninka.ru/article/n/prosvetitelnaya-deyatelnost-zemstv-urala-na-rubezhe-xix-xx-vekov-narodnye-doma

${ }^{15}$ N.V. Kazakova, "Organization of people's houses in pre-revolutionary Udmurtia at the beginning of the $20^{\text {th }}$ century," Idnakar: methods of historical and cultural reconstruction, no. 3 (2015), accessed January 10, 2020, https://cyberleninka.ru/article/n/organizatsiya-narodnyh-domov-v-dorevolyutsionnoy-udmurtii-nachala-hh-v

${ }^{16}$ V.K. Alekseyeva, Kooperativnoye dvizheniye v Sibiri. Konets XIX-nachalo XX v. (Novosibirsk: Izdatel'stvo Novosibirskogo universiteta Publ., 1993), 103.

17 T.G. Maltseva, " $125^{\text {th }}$ anniversary of the formation of the Society for the Care of Primary Education in Altai," Barnaul Chronograph, http://www.altlib.ru/ files/text/h2009/03.html; V.A. Skubnevsky, "People's House - the center of cultural and social life of pre-revolutionary Barnaul," Bulletin of Altai State University, no. 4-2 (2012), accessed January 10, 2020, https://cyberleninka.ru/article/n/narodnyy-dom-tsentrkultury-i-obschestvennoy-zhizni-dorevolyutsionnogo-barnaula 
According to V.A. Skubnevskii, the history of Barnaul's people's house began with the work of the Society for the Care of Primary Education. ${ }^{18}$ He found that in the revolutionary years of 1905 to 1907 , the house witnessed political clashes, while O. Iu. Konysheva examined the city's building, which was built in 1900, as an architectural and cultural phenomenon. ${ }^{19}$

The works of Adele Lindenmeyr, a prominent American historian of charity in Imperial Russia, has also paid attention to people's houses there. Her research is distinguished by the theoretical and conceptual depth of her understanding of this phenomenon in the context of charity and civil society. Her warnings about excessive enthusiasm for resorting to binary concepts (traditional vs. contemporary, religious vs. secular, state vs. public), as scholars often do, are particularly noteworthy. As she explains, "Being not always unfounded, binary paradigms nevertheless create an idea of the excessive determinism of history. They prevent us from gaining a more subtle, pluralistic understanding of the complex relations between various authorities and social groups, as well as within them."

By providing concrete examples, Lindenmeyr shows that it is often impossible to draw a clear line between religious and secular motives. "Many of the most innovative, progressive charitable initiatives in the $19^{\text {th }}$ and $20^{\text {th }}$ centuries drew inspiration and guidance from religion," she writes. ${ }^{20}$ In this regard she analyzes the establishment of the Ligovskii people's house in 1903 by Countess Sofia Panina: "Its diverse activities intersected little with the paths of official religion. However, the consecration of the building in 1903 had religious meaning. It was Father Grigori (Petrov), a priest known for his progressive views that Panina chose to conduct the ceremony; moreover, it was the Easter Sunday that was chosen as the day of the consecration ceremony. ${ }^{21}$ " Such examples reveal the complexity and inconsistency, and, paradoxically, harmonious combinations of the secular and religious, traditional and innovative, progressive and archaic in Russia as it evolved towards modernity.

The existing literature allows us to compre people's houses in Western Europe and Russia at the turn of the $20^{\text {th }}$ century in the context of civil society. In particular, this article evaluates the establishment of people's houses, while considering the roles of the public and the state, the influence of political, religious and intellectual motives, as well as their socio-cultural significance. As for Russia, it also pays attention to the little known history of people's houses in rural areas.

\section{The rise of people's houses in Western Europe and Russia}

In both Europe and Russia, heads of state, aristocrats, and industrialists sponsored people's houses. One of the first, the "New Institute for Character Formation," opened in 1816 by Robert Owen in New Lanark, was built by a factory owner for his workers. Already in the $1830 \mathrm{~s}$ and $1840 \mathrm{~s}$, businessmen in Lancaster, Scotland and the northeast of England often established reading rooms and libraries for their workers to retain their labor force, combat drunkenness and other vices that might interfere with their work. ${ }^{22}$

${ }^{18}$ O.Yu. Konysheva, "The People's House in Barnaul is an architectural and cultural monument of the early XX century," Balandin Readings, no. 1 (2015), accessed January 7, 2020, https://cyberleninka.ru/ article/n/narodnyy-dom-v-g-barnaule-pamyatnik-arhitektury-i-kultury-nachala-Xx-v

19 A. Lindenmayyer, "Otkryvaya Atlantidu: tendentsii i perspektivy izucheniya istorii rossiyskoy blagotvoritel'nosti," in Blagotvoritel'nost' v Rossii: Novyye dokumenty i issledovaniya (St. Petersburg: NestorIstoriya Publ., 2008), 99.

${ }^{20}$ Ibid.

${ }^{21}$ G.D. Nash, T.A. Davies, B. Thomas, Workmen's Halls and Institutes: Oakdale Workmen's Institute. National museum of Wales. Cathays Park (Cardiff: Cardiff University, 1995), 3.

${ }^{22} \mathrm{~F}$. Bartlett's letter January 19, 1886, https://www.library.qmul.ac.uk/archives/archive-galleries/thepeoples-palace-past-and-present/name-36377-en.html 
By the end of the $19^{\text {th }}$ century, enormous progress had been made in the field of public education, and the charity of capitalists attracted the attention of monarchs and the nobility.

Among such institutions at the time in Russia the tsar supported was the People's House of Emperor Nicholas II in St. Petersburg at the turn of the twentieth century. Even earlier in 1887, Queen Victoria had opened the People's Palace in the London's East End. Additional funding outside the royal family's purse led to some controversy as some argued that, rather than spending money for the "lazy" working class, it should go to build hospitals and improving their living conditions. ${ }^{23}$ However, the skeptics could not turn the tide of public opinion. This was vividly expressed by Sir Walter Besant, who in the eight chapter of his novel of 1882, All Sorts of Conditions and Men, described the "Palace of Pleasure" that became the prototype of the building the queen opened five years later. According to the author, the palace was meant to rouse the dormant minds of workers, who preferred food and drink, by directing them to higher intellectual and aesthetic pleasures. In his imaginary architecture, there was no place for a pompous staircase occupying a huge space, meaningless enfilades and passages; everything was to be rationally designed to accommodate concerts and performances, dances and playing with children, a library with a reading room, classrooms, and games. ${ }^{24}$ The real people's palace was a majestic structure in the British capital's poor district, which, according to the conventions of Victorian philanthropy, was meant to distract laborers from gin and porter by providing cultural diversions ranging from simple entertainments like donkey shows to sophisticated concert performances. Its premises included technical and engineering schools, a sports hall, a swimming pool, a library, a regular garden, and a winter garden. ${ }^{25}$

In 1898 the Earl of Rosebury solemnly opened the People's Palace in Glasgow's working area. The ground floor of the grand red brick building housed reading and relaxation rooms, a museum, and the top floor featured an art gallery. It houses Glasgow Museum of Social History today; a huge glazed space adjoins the main building, where a magnificent winter garden is located.

Countess Panina's pet project, the Ligovskii People's House, was built in 1903 according to similar principles, "a new symbiosis of education and entertainment," as she put it. According to Adele Lindenmeyr "Rejecting the model of state-funded people's houses under guardianship of sobriety, she conceived the Ligovskii people's house as a spacious and well-equipped haven where workers and their children could not only forget about stuffy slums, but also learn and socialize. ${ }^{26}$ " The countess spoke critically of the people's houses the Ministry of Finance opened to distract people from drunkenness, arguing that such institutions solely provided "entertainment." Advocating the "symbiosis of entertainment and education", Panina and like-minded people were sought for the best way to introduce children and adults to culture. ${ }^{27}$ Her concept of a people's house was in no way connected to politics. In her memoirs, Panina wrote: "Politics, whatever political propaganda was, explicit or implicit, was unanimously excluded from our educational activity."28

The people's houses built on the initiative of workers themselves were a more public version of such institutions. They became important community centers of culture at the turn of the twentieth century. In 1879 a people's house (since in 1982 the Workers Museum Arbejdermuseet) was built in Copenhagen, and during the subsequent decade others emerged elsewhere in Denmark. Elsewhere in the Nordic countries, Tampere saw a House of Workers

${ }^{23} \mathrm{~W}$. Besant, All sorts and conditions of men, an impossible story (New York: Lovell, Coryell, 1882).

${ }^{24}$ Internet Archive, https://ia800702.us.archive.org/33/items/allsortsconditi00besa/allsortsconditi00besa.pdf

${ }^{25}$ The People's palace: past and present, https://www.library.qmul.ac.uk/archives/archive-galleries/thepeoples-palace-past-and-present/

${ }^{26}$ A. Lindenmayyer, "Otkryvaya Atlantidu," 99.

${ }^{27}$ S. Panina, "Na peterburgskoy okraine," Novyy zhurnal, no. 1 (1957): 170-171.

${ }^{28}$ Ibid., 172. 
open in 1900 (where in 1905 V.I. Lenin and J.V. Stalin met for the first time), followed byone in Helsinki eight years later, while in Sweden the phenomenon was associated with the emergence of the labor movement. In Stockholm, the people's house was being built between 1897 and 1901. In 1906, "beautiful halls of the huge six-story People's House"29 hosted the fourth (unifying) Congress of the Russian Social Democratic Labor Party (RSDLP). Meanwhile in neighboring Norway, people's houses began to operate in 1890 in Vikersund and in 1907 in Oslo; in all, the Scandinavian kingdom housed over two hundred such institutions. People's houses in Italy dated back to 1893 and in Switzerland to 1899, while in Austria they were opened between 1902 and 1907.

One of Europe's most important people's houses in Europe was in Brussels. Built at the request of the workers' party of Belgium by cooperatives from 1896 to 1899 and designed by the architect Victor Horta, who widely used the new decorative innovations of metal and Art Nouveau techniques. The building, "full of light and air, which was unusual for slum workers" housed the administration, cooperatives, offices of political and professional organizations, cafes, rooms for education, a huge 1,500 seat hall for party functions, as well as concerts and plays. Over time, the party had people's houses built in every major Belgian city. As its administrative headquarters and meeting places for workers, they symbolized their solidarity and desire for progress, while also contributing to class and political consciousness. Despite its significance and public protests, the Brussels "Maison du Peuple" in Brussels was demolished in 1965. However, many other people's houses have had a happier and longer life.

Already in 1860 , Ateneum ${ }^{30}$ emerged in Barcelona as a center of support for social progress as well as the cultural and political education of the working class, and still operates today to preserve and promote Catalan culture. Catalonia's ateneums were revived as centers of national culture beginning in the 1990s. Such buildings typically house facilities for various events, including a large hall with a stage, a library, a theater, a relaxation room (where, for example, one can play chess), and a cafe or restaurant. In addition to lectures, courses, conferences, discussions, readings, concerts, theater and film shows, the premises often serve as a meeting place for local clubs. These people's houses were created by cooperative efforts, financed (and continue to be supported) by its members and managed by a general meeting. As in much of Europe, their cultural mission was combined with cooperative carried out trade in small shops located on the building's first floor.

The emergence of people's houses or workers' houses in France is also associated with its trade union movement, to defend the interests of workers, promote their cultural development, and as labor exchanges. Many of them still host various meetings, conferences, concerts, exhibitions, plays and other social events.

In the center of Wales' metalworking region laborers jointly built Blaenavon Workmen's Hall in 1895. The large facility was used for concerts, national Welsh poetry and music contests, charity fairs and political gatherings, while the library and reading rooms provided access to newspapers and literature, to broaden the minds of workers and their families. The building also housed a billiard room and a cinema. Today the solid stone structure remains a living cultural institution, with concerts, a billiard room, a cinema, and a museum of the local community's history. UNESCO added it to its World Heritage List as part of the entire Blaevenon industrial landscape.

As in the European examples cited above, the social demand for "rational entertainment" - theatrical performances, concerts, dance, literary, musical evenings, people's readings,

\footnotetext{
${ }^{29}$ K.Ye. Voroshilov, Rasskazy o zhizni (Vospominaniya) (Moscow: Politizdat Publ., 1968), https://leninism.su/ biography/4063-lenin-v-shveczii.html?start=8

${ }^{30}$ The word "Ateneum" (Spanish - el ateneo, cat. - el ateneu) means a folk cultural center, named after the Greek goddess of reason and knowledge, Athena.
} 
people's choirs, tea houses, and folk festivals ${ }^{31}$ - to combat ignorance, vice and drunkenness, also emerged in late imperial Russia. At the constituent assembly of the "People's house" Society in Kurgan, a speaker stated its goals: "Russia is about to take a new path of development and progress. The broad masses of the people desire light. It is the "People's house" that should prepare these masses for the future cause." 32

At the turn of the $20^{\text {th }}$ century people's houses operated in Moscow, St. Petersburg, Ufa, Tomsk, Chelyabinsk, Barnaul, Simbirsk, Vyatka. ${ }^{33}$ The need for public education was also clearly recognized in Russia's more remote regions. Realizing that in European Russia, cultural life was still inert, and "barely awake" in Siberia, ${ }^{34}$ educators beyond the Urals explained, "we are accountable to future generations for every hour of 'lethargy'.,"35

Barnaul's people's house began with the active educational work of the Society for the Care of Primary Education, which the exiled populist V.K. Stilke set up in $1884 .{ }^{36}$ After numerous requests, the city council approved the project. Erected on the foundation of the city prison, which had burnt down, the people's house was formally opened in December 1900. The Society's members organized Sunday readings, lectures, amateur evenings, theatre performances, etc., while their garden featured a tea stall still operated in Soviet times. ${ }^{37}$

Political rallies and demonstrations took place in front of the building during the revolutionary years of 1905 to 1907 , while led more conservative townspeople repeatedly to call for it to be shut. In a meeting on November 21, 1905, middle class citizens demanded that they "close down" the people's house, "to prevent those people who are against God and the Tsar from gathering there." 38 Twelve years later, it was in the same people's house that Soviet power was proclaimed in Altai. At the time, it hosted two free public schools, people's, school and public libraries, a book depository, a summer public theater, a garden for urban residents, and held various events, such as meetings and charity concerts.

The people's house was the center of the population's cultural and social life, and it housed a wide variety of groups, including trade unions, the Society of Doctors, the Council of Workers and Military Deputies and Socialist Revolutionaries, the Fire Society and the Ukrainian Gromada, Czech prisoners of war, the Polish organization, the Russian Red Cross, Old Believers, Mensheviks and Social Democrats. The building remained a cultural center in the Soviet period and during the Great Patriotic War, it housed the Dnepropetrovsk Russian Drama Theater and the Moscow Chamber Theater (1941-43), which had been evacuated to Barnaul.

${ }^{31}$ N.V. Kazakova, "Organization of people's houses in pre-revolutionary Udmurtia at the beginning of the $20^{\text {th }}$ century," Idnakar: methods of historical and cultural reconstruction, no. 3 (2015), accessed January 10 , 2020, https://cyberleninka.ru/article/n/organizatsiya-narodnyh-domov-v-dorevolyutsionnoy-udmurtii-nachala-hh-v

${ }^{32}$ Gosudarstvennyy arkhiv Novosibirskoy oblasti (thereafter-GANO), f. D-97, op. 1, d. 60, 1. 1.

${ }^{33}$ N.V. Kazakova, "Organization of people's houses in pre-revolutionary Udmurtia at the beginning of the $2^{\text {th }}$ century," Idnakar: methods of historical and cultural reconstruction, no. 3 (2015), accessed January 10 , 2020, https://cyberleninka.ru/article/n/organizatsiya-narodnyh-domov-v-dorevolyutsionnoy-udmurtii-nachala-hh-v

${ }^{34}$ GANO, f. D-97, op. 1, d. 60, 1. 67.

35 Ibid., 1. $67 \mathrm{ob}$.

36 T.G. Maltseva, " $125^{\text {th }}$ anniversary of the formation of the Society for the Care of Primary Education in Altai," Barnaul Chronograph, http://www.altlib.ru/ files/text/h2009/03.html; V.A. Skubnevsky, "People's House - the center of cultural and social life of pre-revolutionary Barnaul," Bulletin of Altai State University, no. 4-2 (2012), accessed January 10, 2020, https://cyberleninka.ru/article/n/narodnyy-dom-tsentrkultury-i-obschestvennoy-zhizni-dorevolyutsionnogo-barnaula

${ }^{37}$ O.Yu. Konysheva, "The People's House in Barnaul is an architectural and cultural monument of the early XX century," Balandin Readings, no. 1 (2015), accessed January 7, 2020, https://cyberleninka.ru/ article/n/narodnyy-dom-v-g-barnaule-pamyatnik-arhitektury-i-kultury-nachala-XX-v

${ }^{38}$ V.A. Skubnevsky, "People's House - the center of cultural and social life of pre-revolutionary Barnaul," Bulletin of Altai State University, no. 4-2 (2012), accessed January 10, 2020, https://cyberleninka.ru/article/n/ narodnyy-dom-tsentr-kultury-i-obschestvennoy-zhizni-dorevolyutsionnogo-barnaul 
The cooperative movement that originated in Europe also actively developed in Asian Russia. As in Western Europe, Siberian cooperatives were busy in the cultural and educational field. They opened reading rooms, organized lectures, family literary and musical evenings, and concerts of professional artists. On December 6, 1918, the report to the general meeting of shareholders of the regional union of the Trans-Baikal cooperative, "On the cultural and educational department of the Trans-Baikal cooperation", stated, "To facilitate the emergence of people's houses, clubs, tea houses, etc. in the region it is necessary to establish a 'people's house fund' from which grants should be given to cultural and educational organizations for equipping ready-made premises, and salaries to hire managers and organizers. Money from these two funds should be spent in the form of temporary or non-repayable loans." 39

Not all public initiatives to open people's houses were successful. In Novonikolaevsk, the Society for the Care of Public Education, which was established in 1909, was kept from realizing its ambition due to World War I. Its own attempts to raise funds were not very effective, and an urgent appeal to the Ministry of Education and the City Council of Novonikolaevsk for money to complete the people's house in Novonikolaevsk or at least cover the cost of 700,000 bricks for laying its walls - went unanswered. ${ }^{40}$ Thus, a people's house that could have become one of the most beautiful buildings in Novonikolaevsk and hosted an excellent theater, was never built.

The 1915 report of the lawyer G.I. Zhernovkov, a member of the Novikolaevsk Society of Public Education noted that

in the context of the movement for people's sobriety, despite the war, the Ministry of Education proposed a bill on people's houses and other educational out-of-school institutions to the State Duma. Zemstvos came up with plans for a regional network of people's houses. The Moscow, Tver, Viatka, Yaroslavl, Perm, Ufa, Poltava and Kiev zemstvos began developing regional networks of public houses. The Commission at the Samara City Council proposed building people's houses and people's theaters ... The Kazan City Council allocated 10,000 rubles for people's entertainment in workingclass quarters. Poltava's provincial zemstvo allocated 15,000 rubles for the establishment of people's houses in the county. For the same purpose, Kiev's zemstvo allocated 30,000 rubles, ${ }^{41}$ Vyatka's 105,000 rubles, Moscow's - 100,000 rubles. In 1914, Perm's provincial zemstvo generously allocated a million rubles for people's houses, provided that they were built within ten years. ${ }^{42}$

As the most successful in organizing people's houses in the countryside, Perm Province's zemstvo deserves a closer look. The county zemstvos were entrusted with creating a network of people's houses together with local rural societies or cooperatives. The provincial government was to write their charters and the conditions for issuing loans to build them. The opening of cultural institutions in villages was considered to be an urgent need: "Without any cultural guidance, in villages the people unwittingly spend their leisure time on drunkenness or frivolous amusements, which certainly contributes to the deterioration of morals and the rise of the evil that has now commonly become as hooliganism."

People's houses were mean to save the population from these ills by providing new cultural opportunities, and the government felt that every people's house should have a library-reading room, under the jurisdiction of the county zemstvo. They were also supposed to provide villages with venues for theatrical performances, people's readings, lectures, conversations using magic lanterns, cinema, dance and music evenings, as well as other entertainments. At the same time, the buildings were designed for both young people who wanted to enjoy themselves and relax on a holiday, and for adults, "respectable

${ }^{39}$ O.Yu. Konysheva, "The People's House in Barnaul is an architectural and cultural monument of the early XX century," Balandin Readings, no. 1 (2015), accessed January 7, 2020, https://cyberleninka.ru/ article/n/narodnyy-dom-v-g-barnaule-pamyatnik-arhitektury-i-kultury-nachala-XX-v

${ }^{40}$ GANO, f. D - 97, op. 1, d. 60, 1. 20 ob.

${ }^{41}$ Ibid., 1. $19 \mathrm{ob}$.

${ }^{42}$ Ibid., d. 60, 1. 20. 
house owners who had an opportunity to read a newspaper during their leisure, discuss the news and generally talk about public affairs." At the same time, a people's house could host the meetings of all public organizations of a village, including fire brigades, credit partnerships, agricultural and consumer societies.

It was assumed that it the provincial zemstvo, the local committee to promote national sobriety and the local society itself, on whose initiative a people's house was organized, would jointly pay for building it. Once opened, the facility would be managed and funded by the corresponding rural society, or by all the all local public organizations that had contributed the money. A contemporary indicated that in Perm, Poltava and other provinces "cooperatives are the hottest and liveliest conduits of the idea of people's houses." 43

Indeed, Perm Province's cooperative congresses enthusiastically responded to the idea of creating people's houses. Thus, the congress of the Shadrinsk district in 1911 issued a resolution on cultural work. The cooperative congress in Kamyshlovsk uezd decided in 1913 that attention should be paid to the organization of people's houses, declaring it to be "a matter where all cooperatives could unite. This is a great, holy idea." The question was discussed in 1913 at the meeting of representatives of credit and agricultural cooperatives in Osa. One of its participants pointed out that, instead of the usual type of buildings for agricultural warehouses, it would be better to build people's houses, with a stage, library, and a boardroom room on the upper floor, and the warehouse of agricultural tools and seeds on the lower.

In 1912 and 1913, the provincial administration received 41 requests for subsidies to build people's houses. The applicants included 14 credit partnerships, six rural societies, five "People's house" organizations, three cities, two fire brigades, two agricultural societies, and one each from a school-volost guardianship, a temperance society, and a theater circle.

The largest number of applications, about $40 \%$, came from credit partnerships. According to a contemporary, this is understandable, as "Credit partnerships are the most stable economic organizations now, involving the cultural element of the modern village. The importance of credit partnerships can hardly be disputed, and their initiative to organize people's houses is highly desirable." In urgent need of their own premises, these groups expected to use the buildings to house their offices as well. In particular, the Shadrinsk district zemstvo paid serious attention to this need of the credit partnerships. The individual cited above thought that it would be most expedient to combine all village organizations involved in the people's house into one, while the building could fully satisfy the goals of all public institutions.

There were various justifications for organizing people's houses. It was generally felt that people wanted to be educated, while they were also seen "as a sure means of distracting the youth from alcohol abuse and hooliganism." When applying for a subsidy for a building, the Nizhne-Serginsk Society people's house in Krasnoufimsk uezd noted that, while there were many schools in the factory settlement of 20,000 inhabitants,

and there are a lot of literate people here, but just literacy is not enough. A school graduate here has no opportunity to develop his knowledge, since there are no refresher courses or a public library. The tavern is the place where there are two or three newspapers. The people's house society at the factory plans, to the best of its ability, to give the local residents an opportunity to spend their free time in a more or less useful and rational way. ${ }^{44}$

People's houses are a good example of the interplay of modern and traditional values in Russia at the time. On December 6, 1908, the day of the patron saint of the local tempe-

43 N. Beldytskiy, "Ob organizatsii Narodnykh Domov v Permskoy gubernii," Permskaya zemskaya nedelya, no. 15 (1914): 3-7.

${ }^{44}$ Permskaya zemskaya nedelya, no. 16 (1914): 18; Permskaya zemskaya nedelya, no. 17 (1914): 17. 
rance society, St. Nicholas the Wonderworker, a modest celebration took place in Aramilskii village. The Trinity Church's clergy consecrated the people's house at the temperance society, which was built on the church square. After the liturgy, the procession carried a revered icon of St. Nicholas from the church to the people's house and prayed before it. The priest, who headed the temperance society, delivered a speech about the population's need for a people's house, the purpose of its creation, and he thanked the society's treasurer, I.G. Guskin, who had worked hard to build it at a cost of 1,200 rubles. After the house was consecrated, the local choir performed a liturgical concert, while tea and refreshments were served to the teetotalers and visitors. Photographs were then taken of the guests with the local dean, as well as of the church and the temperance society's new building. The structure was to host a tea room, a library-reading room, people's readings with magic lantern shows, as well as concerts. Meanwhile, its abstemious members could meet and exchange thoughts about ways to combat drunkenness. The observer noted, "Thus, there will be closer interaction, mutual support, and the meeting of the temperance society's members in their own premises, where they can feel freer than in church, play musical instruments and sometimes even stage performances to distract the weak and the poor from addiction to intoxicating beverages in their dull, laborious, and monotonous lives." 45

\section{Conclusion}

By the turn of the $20^{\text {th }}$ century the traditional views of Europeans had undergone significant changes. People's houses were one response to their growing thirst for culture and education. In the West, they can trace their roots to the early nineteenth century's utopian social projects. Developing in the second half, they reached their peak during the following century's first decade. The phenomenon of people's houses in European countries and in Russia tends be similar both with the rise of socialist movements and flowering of architectural Art Nouveau. Their facades were often decorated in the best traditions of the style, paying tribute to a workman. The exterior of Antwerp's people's house, which was opened in 1901, features mosaics of a sower, a carpenter, a bricklayer, and a metallurgist. Thus, people's houses were socially significant centers for the formation of a new type of person - a worker-creator, who was educated, cultured, and socially active.

Both in Europe and in Russia, people's houses were created as centers of cultural leisure and education to combat vice and drunkenness among working people. The government supported the efforts to promote abstinence, although civil society was more effective in building them, with the cooperative movement playing an important role. The distinguishing feature in Russia was the participation of the zemstvos, which also provided financial support.

People's houses emerged almost simultaneously as non-state social entities. Unlike their Western analog, in Russia, despite being the site of revolutionary disturbances during 1905 and afterwards, they did not house political organizations. This difference was due to the late formation of the party system there. Whereas in Europe many people's houses were established by political organizations and were often highly politicized, the reverse was true for Russia, where they were established as cultural and educational public institutions that became exposed to politics due to revolutionary unrest.

Europe's people's houses were closely tied to socialist parties, as was typical of civil society there at the time. However, in the Russian Empire, civil society was still in its infancy. ${ }^{46}$ Meanwhile, even provincial civic activity was growing there, and people's

${ }^{45}$ Yekaterinburgskiye yeparkhial'nyye vedomosti, no. 17 (1909): 257-258.

${ }^{46}$ Ye.Yu. Kazakova-Apkarimova, Formirovaniye grazhdanskogo obshchestva: gorodskiye soslovnyye korporatsii i obshchestvennyye organizatsii na Srednem Urale vo vtoroy polovine XIX-nachale XX v. (Ye- 
houses occupied a special niche, with close ties to other public institutions, including trade unions, cultural, educational and religious associations, the Church, and, eventually, political parties.

In short, because of their many functions, collective involvement, independence, social activism and civic consciousness, people's houses were tremendously important elements of civil society in Europe and Russia at the turn of the twentieth century.

Рукопись поступила: 18 февраля 2020 г.

Submitted: 18 February 2020.

\section{References}

Alekseyeva, V.K. Kooperativnoye dvizheniye v Sibiri. Konets XIX-nachalo XX v. Novosibirsk: Izdatel'stvo Novosibirskogo universiteta Publ., 1993 (in Russian).

Alekseyeva, V.K., and Malakhova, G.M. Kooperatsiya v Aziatskoy Rossii (pervoye stoletiye). Chita: Izdatel'stvo ZIP SibUPK Publ., 2004 (in Russian).

Beldytskiy, N. "Ob organizatsii Narodnykh Domov v Permskoy gubernii." Permskaya zemskaya nedelya, no. 15 (1914): 3-7 (in Russian).

Besant, W. All sorts and conditions of men, an impossible story. New York: Lovell, Coryell, 1882.

Druzhinina, E.B. "The first, not accidental, remarkable... (to the $110^{\text {th }}$ anniversary of the building of the people's house in Chelyabinsk)." Museum Bulletin, no. 16 (2014): 64-68.

Cossart, P., and Talpin, J. "Les Maisons du Peuple comme espaces de politisation. Étude de la cooperative ouvrière la paix à Roubaix (1885-1914)." Revue française de science politique 62, no. 4 (2012): 583-610 (in Russian).

Hastings, M. Halluin la rouge 1919-1939, aspects d'un communism identitaire. Paris: Presses University, 1991 (in French)

Hoffsten, A. Das Volkshaus der Arbeiterbewegung in Deutschland: Gemeinschafts bauten zwischen Alltag und Utopie. Köln; Wien; Weimar: Böhlau Verlag, 2017 (in German).

Kazakova-Apkarimova, Ye.Yu. Formirovaniye grazhdanskogo obshchestva: gorodskiye soslovnyye korporatsii i obshchestvennyye organizatsii na Srednem Urale vo vtoroy polovine XIX-nachale $X X v$. Yekaterinburg: UrO RAN Publ., 2008 (in Russian).

Kazakova-Apkarimova, Ye.Yu. Formirovaniye sfery grazhdanskoy deyatel'nosti v ural'skom gorode vo vtoroy polovine XIX-nachale XXv. Saarsbryukken: Lambert Academic Publishing Publ., 2012 (in Russian).

Katz, A. "Maisons du Peuple: Marking new Municipal Centers on the Parisian Periphery, 1914-1940." In Architecture de la Culture. Relais du pouvoir Européen. Proceedings of the DocoMomo International Conference, Paris, April 24, 2006, 26-33. Paris: DocoMomo International, 2009 (in French).

Lindenmayyer, A. "Otkryvaya Atlantidu: tendentsii i perspektivy izucheniya istorii rossiyskoy blagotvoritel'nosti." In Blagotvoritel'nost' v Rossii: Novyye dokumenty i issledovaniya, 95-107. St. Petersburg: Nestor-Istoriya Publ., 2008 (in Russian).

Martin, de F. L., Gonzalez L.A. Las Casas del Pueblo socialistas en España (1900-1936). Paris: Ariel Historia, 1997 (in French).

Nash, G.D., Davies, T.A., and Thomas, B. Workmen's Halls and Institutes: Oakdale Workmen's Institute. National museum of Wales. Cathays Park. Cardiff: Cardiff University, 1995.

Panina, S. "Na peterburgskoy okraine." Novyy zhurnal, no. 1 (1957): 170-171 (in Russian).

Pel'kov, D.Ye. "The first folk houses in the Ufa province (1895-1897)." Bulletin of the Chelyabinsk State Academy of Culture and Art, no. 3 (2012): 160-163 (in Russian).

Pel'kov, D.Ye. "Piteynaya reforma v Rossii i deyatel'nost' popechitel'stv o narodnoy trezvosti v 1895-1914 gg. (po materialam Ufimskoy gubernii)." In Yezhegodnaya bogoslovskaya konferentsiya pravoslavnogo Svyato-Tikhonovskogo gumanitarnogo universiteta, 127-129. M.: [B.i.], 2012 (in Russian).

Voroshilov, K.Ye. Rasskazy o zhizni (Vospominaniya). Moscow: Politizdat Publ., 1968 (in Russian).

katerinburg: UrO RAN Publ., 2008); Ye.Yu. Kazakova-Apkarimova, Formirovaniye sfery grazhdanskoy deyatel'nosti v ural'skom gorode vo vtoroy polovine XIX-nachale XXv. (Saarsbryukken: Lambert Academic Publishing Publ., 2012). 


\section{Библиографический список}

Алексеева В.К. Кооперативное движение в Сибири. Конец XIX - начало XX в. Новосибирск. Издательство Новосибирского университета. 1993. $119 \mathrm{c}$.

Алексеева В.К., Малахова Г.М. Кооперация в Азиатской России (первое столетие). Чита: Издательство ЗИП СибУПК, 2004. 213 с.

Белдыцкий Н. Об организации Народных Домов в Пермской губернии // Пермская земская неделя. 1914. № 15. 10. С. 3-7.

Ворошилов К.Е. Рассказы о жизни (Воспоминания). М.: Политиздат, 1968. 366 с.

Дружинина Э.Б. Первое, неслучайное, достопримечательное... (к 110-летию здания народного дома в Челябинске) // Музейный вестник. 2014. № 16. С. 64-68.

Казакова-Апкаримова Е.Ю. Формирование гражданского общества: городские сословные корпорации и общественные организации на Среднем Урале во второй половине XIX - начале ХХ в. Екатеринбург: УрО РАН, 2008. 289 с.

Казакова-Апкаримова Е.Ю. Формирование сферы гражданской деятельности в уральском городе во второй половине XIX - начале XX в. Саарсбрюккен: Lambert Academic Publishing, 2012. $644 \mathrm{c}$.

Линденмайер А. Открывая Атлантиду: тенденции и перспективы изучения истории российской благотворительности // Благотворительность в России: Новые документы и исследования. СПб.: Нестор-История, 2008. С. 95-107.

Панина С. На петербургской окраине // Новый журнал. 1957. № 1. С. 170-171.

Пельков Д.Е. Первые народные дома в Уфимской губернии (1895-1897 гг.) // Вестник Челябинской государственной академии культуры и искусства. 2012. № 3. С. 160-163.

Пельков Д.Е. Питейная реформа в России и деятельность попечительств о народной трезвости в 1895-1914 гг. (по материалам Уфимской губернии) // Ежегодная богословская конференция православного Свято-Тихоновского гуманитарного университета. М.: [Б.и.], 2012. С. 127-129.

Besant W. All sorts and conditions of men, an impossible story. New York: Lovell, Coryell, 1882. $210 \mathrm{p}$.

Cossart P., Talpin J. Les Maisons du Peuple comme espaces de politisation. Étude de la cooperative ouvrière la paix à Roubaix (1885-1914) // Revue française de science politique. 2012. Vol. 62. № 4. P. 583-610.

Hastings M. Halluin la rouge 1919-1939, aspects d'un communism identitaire. Paris: Presses University, $1991.438 \mathrm{p}$.

Hoffsten A. Das Volkshaus der Arbeiterbewegung in Deutschland: Gemeinschafts bauten zwischen Alltag und Utopie. Köln; Wien; Weimar: Böhlau Verlag, 2017. 724 p.

Katz A. Maisons du Peuple: Marking new Municipal Centers on the Parisian Periphery, 1914-1940 // Architecture de la Culture. Relais du pouvoir Européen. Proceedings of the DocoMomo International Conference, Paris, April 24, 2006. Paris: DocoMomo International, 2009. P. $26-33$.

Martin de F. L., Gonzalez L.A. Las Casas del Pueblo socialistas en España (1900-1936). Paris: Ariel Historia, 1997. $264 \mathrm{p}$.

Nash G.D., Davies T.A., Thomas B. Workmen's Halls and Institutes: Oakdale Workmen's Institute. National museum of Wales. Cathays Park. Cardiff: Cardiff University, 1995. 254 p.

\section{Информация об авторах / Information about the authors}

\begin{abstract}
Алексеева Елена Вениаминовна, доктор исторических наук, профессор РАН, ведущий научный сотрудник центра методологии и историографии Института истории и археологии Уральского отделения Российской академии наук.
\end{abstract}

Казакова-Апкаримова Елена Юрьевна, доктор исторических наук, ведущий научный сотрудник центра методологии и историографии Института истории и археологии Уральского отделения Российской академии наук.
Elena V. Alekseeva, Doktor Istoricheskikh Nauk [Dr. habil. hist.], Professor of the Russian Academy of Sciences, leading researcher at the Institute of History and Archeology, Ural Branch of the Russian Academy of Sciences.

Elena Y. Kazakova-Apkarimova, Doktor Istoricheskikh Nauk [Dr. habil. hist.], Leading Researcher at the Institute of History and Archeology, Ural Branch of the Russian Academy of Sciences. 